\title{
Statistical Analysis of Shrinkage Levels of Human Brain Slices Preserved by Sheet Plastination Technique With Polyester Resin
}

\author{
Análisis Estadístico de los Niveles de Retracción de Cortes de Cerebro Humano \\ Conservados mediante la Técnica de Plastinación de Cortes con Resina Poliéster
}

Nicolás Ernesto Ottone ${ }^{1,2,3}$; Marco Guerrero ${ }^{3,4}$; Eduardo Alarcón ${ }^{5,6,7}$ \& Pablo Navarro ${ }^{8}$

OTTONE, N. E.; GUERRERO, M.; ALARCÓN, E. \& NAVARRO, P. Statistical analysis of shrinkage levels of human brain slices preserved by sheet plastination technique with polyester resin. Int. J. Morphol., 38(1):13-16, 2020.

SUMMARY: Plastination is currently the most important anatomical preservation technique due to the possibility of preserving bodies and organs for an indefinite period, in a dry and biosecure form, while preserving the morphological characteristics of the tissues. However, the shrinkage of the samples is also part of the plastination, perhaps becoming one of its few disadvantages. This paper presents the shrinkage caused by the classic technique of sheet plastination with polyester resin (Biodur® P40) in human brain slices, with the aim of statistically establishing the percentages of tissue shrinkage caused by this plastination protocol.

KEY WORDS: Plastination; Polyester; Shrinkage.

\section{INTRODUCTION}

Plastination is an anatomical cadaveric conservation technique created in 1977 by Gunther von Hagens, in Heidelberg, Germany (Ottone 2013, 2018), and which replaces biological and/or fixation fluids with an intermediate solvent (acetone), to then impregnate the samples with different polymers, depending on the technique of plastination chosen, to finally carry out the polymerization of the components incorporated into the samples, to obtain dry and totally durable biological samples (Ottone et al., 2015; Ottone et al., 2016; Vargas et al., 2019). In particular, sheet plastination with polyester resin was initially created for the preservation of brain slices, for the identification of gray and white matters (von Hagens, 1987). Likewise, this technique can be applied to any body region (Ottone et al., 2014; Ottone et al., 2018a,b; Prieto et al., 2019). But in relation to sheet plastination with epoxy resin, polyester technique causes marked shrinkage of the tissues. In relation to this disadvantage of the technique, it is necessary to establish statistically the shrinkage percentages. The aim of this communication was to analyze and establish the shrinkage of brain sections preserved by a classic protocol of sheet plastination with polyester resin Biodur ${ }^{\circledR} \mathrm{P} 40$ in 3 mm thick human brain slices (Guerrero et al., 2019).

\section{MATERIAL AND METHOD}

The sample used consisted of a human brain, fixed and preserved with $10 \%$ formalin for 6 months. This brain was subsequently washed in running water for two weeks. Once the washing was finished, it was sectioned with a precision saw band machine, with stainless steel blade, obtaining 30 thin slices of $3 \mathrm{~mm}$ thickness. Immediately the

\footnotetext{
${ }^{1}$ Laboratory of Plastination and Anatomical Techniques, Research Centre in Dental Sciences (CICO), Dental School, Universidad de La Frontera, Temuco, Chile.

${ }^{2}$ Center of Excellence in Morphological and Surgical Studies (CEMyQ), Medicine School, Universidad de La Frontera, Temuco, Chile.

${ }^{3}$ Doctoral Program in Morphological Sciences, Faculty of Medicine, Universidad de La Frontera, Temuco, Chile.

${ }^{4}$ Cátedra de Anatomía Normal, Facultad de Ciencias Médicas, Universidad Central del Ecuador, Quito, Ecuador.

${ }^{5}$ Unidad de Anatomía Normal, Universidad de Santiago de Chile, Santiago, Chile.

${ }^{6}$ Departamento de Ciencias Químicas y Biológicas - Universidad Bernardo O’Higgins, Santiago, Chile.

${ }^{7}$ Facultad de Ciencias de la Salud, Universidad de las Américas, Chile.

${ }^{8}$ Research Centre in Dental Sciences (CICO), Dental School, Universidad de La Frontera, Temuco, Chile.
} 
brain cuts were placed in dehydration in $100 \%$ acetone, at $25^{\circ} \mathrm{C}$, for 7 days the first acetone bath, and for another 3 more days, for the second acetone bath. Once the sheets were dehydrated, they were placed in Biodur ${ }^{\circledR} \mathrm{P} 40$ polyester resin and the forced impregnation was carried out in a vacuum chamber at room temperature $\left(20^{\circ} \mathrm{C}\right)$. This stage lasted 24 hours. Once the forced impregnation was finished, the curing stage was carried out, which in the first place consisted of the assembly of the curing chambers within which the slices were located, filling the chambers with polyester resin. Once the curing chambers were assembled, they were placed under UV light to accelerate the polymerization of the polyester and to finish the plastination process. Measurements of the slices were made on millimeter sheets at three moments of the protocol: before starting the plastination process, after dehydration and after forced impregnation. The slices showed great differentiation between gray and white matter.

In relation to the statistical analysis, data collection was recorded in a Microsoft Office Excel spreadsheet, a descriptive analysis of the data was performed: mean, median, variance, minimum, maximum, standard error of the mean, standard deviation and coefficient of variation. The normal distribution of the data was established through Shapiro-Wilk test. To establish the difference in means of shrinkage, the student's t-test was used for related samples, in the case of data that follow a normal distribution; and Wilcoxon range test for related samples, in the case of data that follow a non-normal distribution. The alpha error was set at $\mathrm{p}<0.05$. Shrinkage percentage determination, the mean and the values of their confidence interval were transformed into percentage and their result was subtracted from 100:

$$
\text { p. shrinkage }=\left(\frac{\bar{\chi} \text { shrinkage }}{\bar{\chi} \text { before the process }} \times 100\right)-100
$$

The statistical program IBM SPSS Statistics V.23 was used to analyze the data.

\section{RESULTS AND DISCUSSION}

Central tendency data and dispersion obtained from the lateral-lateral slices measurement before plastination process, as well as in after dehydration and after impregnation are shown in Table I. Central distribution values, dispersion and position of lateral-lateral and superior-inferior slices measurements are found in Tables I and II. Average normality distribution can be observed in Table III. Differences determination between the latero-lateral slices is carried out with the Wilcoxon Ranges test for related samples and they are shown in Table IV. Differences determination between superior-inferior slices were performed by the Student's t-test for related samples and were shown in Table V.

There is a statistically significant difference between the initial measurement values and after dehydration and impregnation both, at the lateral-lateral level as well as at the superior-inferior level.

The percentages of shrinkage between initial values and dehydration are between $2.14 \%$ and $6.22 \%$; and with respect to forced impregnation they are between $7.02 \%$ and $10.62 \%$, the latter percentages being the values corresponding to the final shrinkage caused by the technique of sheet plastination with polyester resin that we applied in slices of human brain.

Brown et al. (2002) conducted a study on the levels of shrinkage caused by dehydration with acetone, at room and cold temperature, as well as with methanol. In relation to dehydration at room temperature with acetone, they found that shrinkage was $20.2 \%$ while at cold temperature, the shrinkage was $14.5 \%$. On the other hand, in the dehydration with methanol at room temperature, the shrinkage was

Table I. Distribution of descriptive values of latero-lateral measures of the brain.

\begin{tabular}{|c|c|c|c|c|}
\hline \multicolumn{2}{|l|}{ Statistics } & \multirow{2}{*}{$\begin{array}{c}\text { Before } \\
\text { plastination } \\
\text { process }\end{array}$} & \multirow{2}{*}{$\begin{array}{c}\begin{array}{c}\text { After } \\
\text { dehydration }\end{array} \\
11.83\end{array}$} & \multirow{2}{*}{$\begin{array}{c}\begin{array}{c}\text { After forced } \\
\text { impregnation }\end{array} \\
11.39\end{array}$} \\
\hline Mean & & & & \\
\hline \multirow{3}{*}{$95 \%$ confidence } & Inferior limit & 12.30 & 11.67 & 11.21 \\
\hline & Superior limit & 12.59 & 11.99 & 11.56 \\
\hline & & 12.50 & 11.95 & 11.50 \\
\hline Variance & & 0.07 & 0.09 & 0.11 \\
\hline Standard deviation & & 0.27 & 0.30 & 0.33 \\
\hline Minimum & & 11.70 & 11.10 & 10.70 \\
\hline Maximum & & 12.90 & 12.20 & 11.80 \\
\hline Range & & 1.20 & 1.10 & 1.10 \\
\hline Standard error & & 0.07 & 0.08 & 0.08 \\
\hline Coefficient of variation & & 2.17 & 2.56 & 2.87 \\
\hline
\end{tabular}


Table II. Distribution of descriptive values of the upper-lower measures of the brain.

\begin{tabular}{|c|c|c|c|c|}
\hline \multicolumn{2}{|l|}{ Statistics } & \multirow{2}{*}{$\begin{array}{c}\text { Before } \\
\text { plastination } \\
\text { process }\end{array}$} & \multirow{2}{*}{$\begin{array}{c}\begin{array}{c}\text { After } \\
\text { dehydration }\end{array} \\
8.65\end{array}$} & \multirow{2}{*}{$\begin{array}{c}\begin{array}{c}\text { After forced } \\
\text { impregnation }\end{array} \\
8.23\end{array}$} \\
\hline Mean & & & & \\
\hline $95 \%$ confidence & Inferior limit & 8.87 & 8.47 & 8.07 \\
\hline interval $(\mathrm{CI})$ for & Superior limit & 9.18 & 8.83 & 8.40 \\
\hline Median & & 9.00 & 8.70 & 8.25 \\
\hline Variance & & 0.09 & 0.12 & 0.10 \\
\hline Standard deviation & & 0.30 & 0.34 & 0.31 \\
\hline Minimum & & 8.50 & 7.90 & 7.40 \\
\hline Maximum & & 9.60 & 9.10 & 8.70 \\
\hline Range & & 1.10 & 1.20 & 1.30 \\
\hline Standard error & & 0.07 & 0.09 & 0.08 \\
\hline Coefficient of variation & & 3.32 & 3.93 & 3.77 \\
\hline
\end{tabular}

Table III. Shapiro-Wilk statistical test to determine the normal distribution of the values of the average of the measurements of the cerebral slices.

\begin{tabular}{lc}
\hline & $\mathrm{p}$-value \\
\hline Before plastination process - Lateral-Lateral & 0.045 \\
Before plastination process - Superior-Inferior & 0.996 \\
After dehydration - Lateral-Lateral & 0.029 \\
After dehydration - Superior-Inferior & 0.407 \\
After forced impregnation - Lateral-Lateral & 0.013 \\
After forced impregnation - Superior-Inferior & 0.085 \\
\hline
\end{tabular}

Table IV. Comparison of laterolateral measures to establish the difference of samples using the Wilcoxon Ranges test for related samples.

\begin{tabular}{ccccc}
\hline & $\mathrm{z}$ & $\mathrm{p}$-value & \% Shrinkage & CI 95\% \\
\hline A & 3.54 & 0.0004 & 4.92 & $3.65-6.22$ \\
B & 3.54 & 0.0004 & 8.94 & $7.02-9.89$ \\
\hline
\end{tabular}

Table V. Differences determination between superior-inferior slices were performed by the Student's t-test for related samples.

\begin{tabular}{ccccc}
\hline & $\mathrm{t}$ & $\mathrm{p}$-va lue & \% Shrinkage & CI 95\% \\
\hline $\mathrm{A}$ & 5.417 & 0.000 & 4.16 & $2.14-6.17$ \\
$\mathrm{~B}$ & 13.668 & 0.000 & 8.8 & $6.97-10.62$ \\
\hline
\end{tabular}

greater, of $22.6 \%$. However, in relation to dehydration with acetone at room temperature, for Holladay (1988) was 35\%, as well as for Schwab \& von Hagens (1981). On the other hand, Sora \& Brugger (2002) analyzed the levels of tissue shrinkage during plastination with epoxy resin, finding a shrinkage between 2 and $4 \%$ after dehydration and between 6 and $10 \%$ at the end of the entire epoxy resin plastination process.

In this sense, our results are closer to what was established by Sora \& Brugger when considering the dehydration in cold temperature $\left(-25^{\circ} \mathrm{C}\right)$. In this way, as established by von Hagens (1985) it can be concluded that dehydration with low temperatures $\left(-25^{\circ} \mathrm{C}\right.$ to $\left.5^{\circ} \mathrm{C}\right)$ will allow less tissue shrinkage.

OTTONE, N. E.; GUERRERO, M.; ALARCÓN, E. \& NAVARRO, P. Análisis estadístico de los niveles de retracción de cortes de cerebro humano conservados mediante la técnica de plastinación de cortes con resina poliéster. Int. J. Morphol., 38(1):13-16, 2020.

RESUMEN: La plastinación es actualmente la técnica de preservación anatómica más importante debido a la posibilidad de preservar los cuerpos y órganos por un período indefinido, en forma seca y biosegura, al tiempo que preserva las características morfológicas de los tejidos. Sin embargo, la retracción de las muestras también es parte de la plastinación, quizás convirtiéndose en una de sus pocas desventajas. Este artículo presenta la retracción causada por la técnica clásica de plastinación de cortes con resina poliéster (Biodur® P40) en cortes de cerebro humano, con el objetivo de establecer estadísticamente los porcentajes de retracción de tejidos causados por este protocolo de plastinación.

PALABRAS CLAVE: Plastinación; Poliéster; Retracción.

\section{REFERENCES}

Brown, M. A.; Reed, R. B. \& Henry, R. W. Effects of dehydration mediums and temperature on total dehydration time and tissue shrinkage. J. Int. Soc. Plastination, 17:28-33, 2002.

Guerrero, M.; Vargas, C.; Alarcón, E.; del Sol, M. \& Ottone, N. E. Development of a sheet plastination protocol with polyester resin applied to human brain slices. Int. J. Morphol., 37(4):1557-63, 2019.

Holladay, S. D. Experiments in dehydration techniques. J. Int. Soc. Plastination, 2(2):17-20, 1988.

Ottone, N. E. Gunther von Hagens, Creador de la plastinación. Reseña histórica y desarrollo de la técnica. Rev. Argent. Anat. Online, 4(2):70$6,2013$. 
Ottone, N. E. Plastination: Techniques fundamentals and implementation at Universidad de La Frontera. J. Health Med. Sci., 4(4):293-302, 2018.

Ottone, N. E.; Baptista, C.; Latorre, R.; Bianchi, H. F.; del Sol, M. \& Fuentes, R. E12 sheet plastination - Techniques and applications. Clin. Anat., 31(5):742-56, 2018a.

Ottone, N. E.; Cirigliano, V.; Bianchi, H. F.; Medan, C. D.; Algieri, R. D.; Borges Brum, G. \& Fuentes, R. New contributions to the development of a plastination technique at room temperature with silicone. Anat. Sci. Int., 90(2):126-35, 2015.

Ottone, N. E.; Cirigliano, V.; Lewicki, M.; Bianchi, H. F.; Aja Guardiola, S.; Algieri, R. D.; Cantin, M. \& Fuentes, R. Plastination Technique in laboratory rats: An alternative resource for teaching, surgical training and research development. Int. J. Morphol., 32(4):1430- 5, 2014.

Ottone, N. E.; del Sol, M. \& Fuentes, R. Report on a sheet plastination technique using commercial epoxy resin. Int. J. Morphol., 34(3):103943, 2016.

Ottone, N. E.; Vargas, C. A.; Veuthey, C.; del Sol, M. \& Fuentes, R. Epoxy sheet plastination on a rabbit head-new faster protocol with Biodur ${ }^{\circledR}$ E12/E1. Int. J. Morphol., 36(2):441-6, 2018b.

Prieto, R.; Vargas, C. A.; Veuthey, C.; Aja-Guardiola, C. \& Ottone, N. E. Fundamental concepts of the modified room temperature plastination protocol with silicone, with subsequent pigmentation, and its application for the conservation of human placenta. Int. J. Morphol 37(1):375-6, 2019.

Schwab, K. \& von Hagens, G. Freeze substitution of macroscopic specimens for plastination. Acta Anat., 111:139-40, 1981.

Sora, M. C.; Brugger, P. C. \& Strobl, B. Shrinkage during E12 plastination. J. Int. Soc. Plastination, 17:23-7, 2002.

Vargas, C. A.; Baptista, C. A. C.; del Sol, M.; Sandoval, C.; Vásquez, B.; Veuthey, C. \& Ottone, N. E. Development of an ultrathin sheet plastination technique in rat humeral joints with osteoarthritis induced by monosodium iodoacetate for neovascularization study. Anat. Sci. Int., 2019. doi: 10.1007/s12565-019-00500-7

von Hagens, G. Heidelberg Plastination Folder: Collection of all technical leaflets for plastination. Heidelberg, Anatomisches Institut I, Universitat Heidelberg, 1985.
Corresponding author:

Prof. Pablo Navarro C., PhD, MSc, MSc, MSc, B.S.

Facultad de Odontología

Universidad de La Frontera

Temuco

CHILE

Email: pablo.navarro@ufrontera.cl

Recibido : 01-08-2019

Aceptado: 05-09-2019 